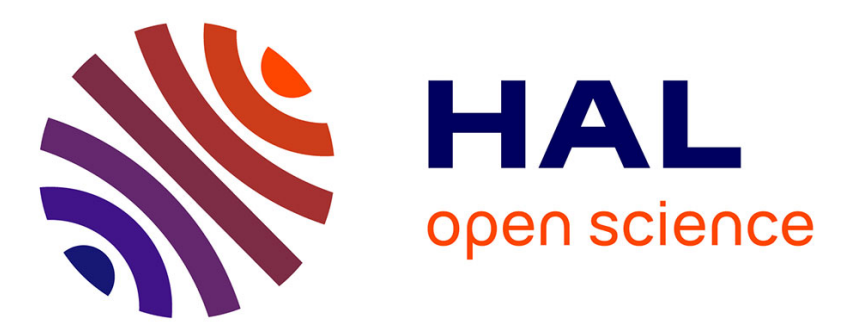

\title{
A scientific note on the first records of Melaloncha Brues, 1904 (Diptera: Phoridae) parasitizing Euglossini and Centridini bees
}

Danilo Ament, Gabriele Freiria, Léo Rocha-Filho, Marco Lama, Carlos Garófalo

\section{To cite this version:}

Danilo Ament, Gabriele Freiria, Léo Rocha-Filho, Marco Lama, Carlos Garófalo. A scientific note on the first records of Melaloncha Brues, 1904 (Diptera: Phoridae) parasitizing Euglossini and Centridini bees. Apidologie, 2014, 45 (2), pp.266-268. 10.1007/s13592-013-0246-1 . hal-01234723

HAL Id: hal-01234723

https://hal.science/hal-01234723

Submitted on 27 Nov 2015

HAL is a multi-disciplinary open access archive for the deposit and dissemination of scientific research documents, whether they are published or not. The documents may come from teaching and research institutions in France or abroad, or from public or private research centers.
L'archive ouverte pluridisciplinaire HAL, est destinée au dépôt et à la diffusion de documents scientifiques de niveau recherche, publiés ou non, émanant des établissements d'enseignement et de recherche français ou étrangers, des laboratoires publics ou privés. 


\title{
A scientific note on the first records of Melaloncha Brues, 1904 (Diptera: Phoridae) parasitizing Euglossini and Centridini bees
}

\author{
Danilo César Ament ${ }^{1}$, Gabriele Antico Freiria ${ }^{2}$, Léo Correia da Rocha-Filho ${ }^{1}$, Marco Antonio del Lama ${ }^{2}$, \\ Carlos Alberto GarófaLo ${ }^{1}$ \\ ${ }^{1}$ Faculdade de Filosofia, Ciências e Letras de Ribeirão Preto, Departamento de Biologia, Universidade de São Paulo, \\ Av. Bandeirantes 3900, 14040-901, Ribeirão Preto, SP, Brazil \\ ${ }^{2}$ Departamento de Genética e Evolução, Universidade Federal de São Carlos, Rod. Washington Luís Km 235, \\ SP 310, 13565-905, São Carlos, SP, Brazil
}

Received 5 July 2013 - Revised 6 September 2013 - Accepted 23 September 2013

parasitism / phorid / immature

The phorid genus Melaloncha Brues, 1904, also known as bee-killing flies, actually comprises 167 species and can be found mostly in the Neotropical region (Brown 2009). Most of the Melaloncha are endoparasitoids of corbiculate, eusocial bees, as stingless bees (Meliponini), bumble bees (Bombus Latreille), and honey bees (Apis mellifera (Linnaeus)) (Ramírez 1982; Brown 2006). Additionally, there are records of species of the genus Melaloncha attacking a noncorbiculate bee of the family Halictidae and a social wasp of the genus Polybia (Lutz and Brown 2013; Wcislo et al. 2004). This note comprises the first records of Melaloncha parasitizing Euglossini and Centridini bees. Melaloncha specimens were collected in southeastern Brazil parasitizing Euglossa cordata (Linnaeus), Euglossa townsendi Cockerell, and Centris analis (Fabricius).

The Euglossa parasitoids were identified as Melaloncha ronnai Borgmeier while the Melaloncha attacking $C$. analis could not be identified to species as only its pupa was collected. $M$. ronnai is one of the best studied species of the genus, with its life cycle thoroughly described from specimens attacking $A$. mellifera (Ronna 1936). Considering that A. mellifera

Corresponding author: D.C. Ament, danament@gmail.com Manuscript editor: Klaus Hartfelder was introduced in the Neotropical region, the original host of M. ronnai was still considered doubtful (Brown 2004). All the examined specimens are deposited in the Museu de Zoologia da Universidade de São Paulo, Brazil (MZSP).

M. ronnai Borgmeier (Figure 1a-c, puparium)

New examined material. 1f\# with puparium, Ribeirão Preto, São Paulo, Brazil, $21.16^{\circ} \mathrm{S}$, 47.85 $\mathrm{W}, 03 . i x .2010$, adult emerged from a founder female of E. cordata, Garófalo C.A. col.; 1f\# with puparium, São Carlos, São Paulo, Brazil, 22.01오 $47.89^{\circ} \mathrm{W}, 27 . v .2013$, adult emerged from a forager female of E. cordata, Freiria G.A. col.; $1 \mathrm{m \#}$ with puparium, São Carlos, São Paulo, Brazil, $21.59^{\circ} \mathrm{S}$, $47.52^{\circ} \mathrm{W}, 26 . i v .2013$, adult emerged from a founder female of E. townsendi, Freiria G.A. col.

The three puparia were found occupying almost completely the internal area of the mesosoma of the bee, upside down. M. ronnai puparium is very similar to the one of a Melaloncha species described by Lucia et al. (2013), a Bombus parasitoid, differing only by its shorter length $(3.5 \mathrm{~mm}$ in comparison with the $5 \mathrm{~mm}$ puparium of the Bombus parasitoid).

Melaloncha sp. (Figure 1d-h, puparium and pupa)

Examined material. One pupa from Ribeirão Preto, São Paulo, Brazil, 21.16 ${ }^{\circ} \mathrm{S}, 47.85^{\circ} \mathrm{W}, 03 . i x .2010$, Rocha-Filho L.C. col. 

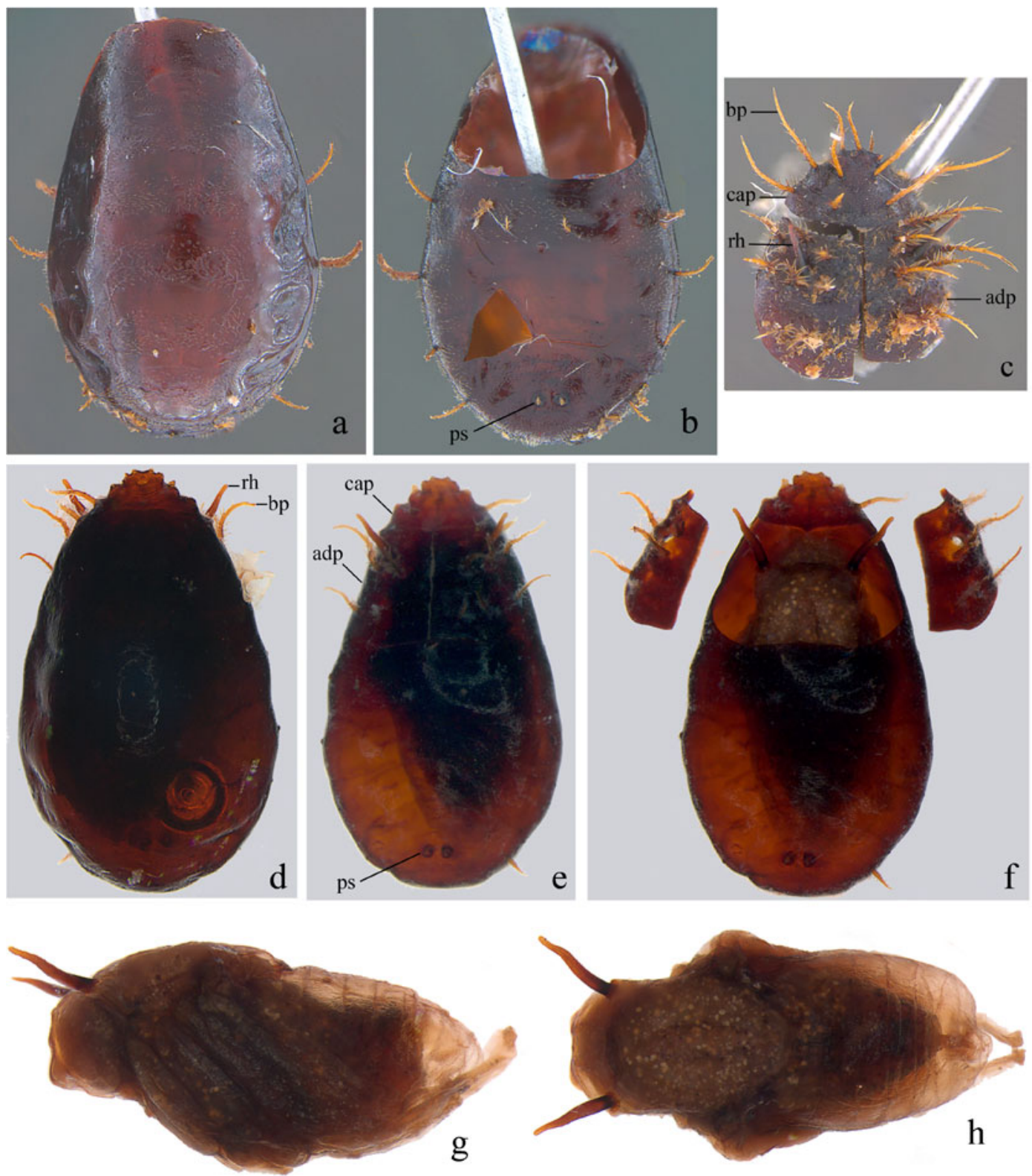

Figure 1. Melaloncha puparium and pupa. a-c Melaloncha ronnai. a Puparium basal part in ventral view, b puparium basal part in dorsal view, $\mathbf{c}$ detachable cap and anterodorsal plates. $\mathbf{d}-\mathbf{h}$ Melaloncha sp., $\mathbf{d}$ puparium in ventral view, $\mathbf{e}$ puparium in dorsal view, $\mathbf{f}$ puparium dorsal with anterodorsal plates removed, $\mathbf{g}$ pupa in left lateral view, $\mathbf{h}$ pupa in dorsal view. $a d p$ Anterodorsal plate, $b p$ branched projections, $p s$ posterior spiracle, $r h$ respiratory horn.

The puparium was removed from the interior of the mesosoma of a $C$. analis, which constitutes the first record of a Melaloncha attacking a Centridini bee. It is very similar to the M. ronnai puparium, but with slightly shorter branched projections.

\section{ACKNOWLEDGEMENTS}

We would like to thank Diego Sasso Porto by finding the parasitoid inside the $C$. analis during his studies. This study benefited from FAPESP grants: 
2011/03563-0 (first author), 2011/13363-9 (second author) and 2010/52531-1 (third author).

Note scientifique: première observation de Melaloncha Brues, 1904 (Diptera: Phoridae) parasitant des abeilles Euglossines et Centridines

Eine wissenschaftliche Notiz über eine Erstbeschreibung von Melaloncha Brues, 1904 (Diptera: Phoridae) als Parasit von Bienenarten de Euglossini und Centridini

\section{REFERENCES}

Brown, B.V. (2004) Revision of the subgenus Udamochiras of Melaloncha bee-killing flies (Diptera: Phoridae: Metopininae). J. Linn. Soc. LondonZool. 140, 1-42

Brown, B.V. (2006) Revision of the untreated taxa of Melaloncha $\mathrm{s}$. s. bee-killing flies (Diptera: Phoridae). Zootaxa 1280, 1-68
Brown, B.V. (2009) Three new species of parasitoid Phoridae (Diptera) from the Neotropical Region. Sociobiology 54(3), 715-722

Lucia, M., Alvarez, L.J., Abrahamovich, A.H. (2013) First record of Melaloncha (Diptera: Phoridae) parasitoid associated with Bombus (Apidae: Bombini) in Argentina. J. Apic. Res. 52(2), 72-73

Lutz, M.A., Brown, B.V. (2013) New host association: Polybia scutellaris (Hymenoptera, Vespidae) parasitized by Melaloncha (Diptera, Phoridae). Rev. Bras. Entomol. 57(2), 238-239

Ramírez, W. (1982) Bombus mexicanus Cresson, un hospedante de Melaloncha, moscas parásitas de la abeja de miel en el nuevo mundo. Rev. Biol. Trop. 30, 177

Ronna, A. (1936) Observações biologicas sobre dois dípteros parasitas de Apis mellifica [sic] L. (Dipt. Phoridae, Sarcophagidae). Rev. Bras. Entomol. 6, 1-9

Wcislo, W.T., Arneson, L., Roesch, K., Gonzalez, V., Smith, A., Fernández, H. (2004) The evolution of nocturnal behaviour in sweat bees, Megalopta genalis and M. ecuadoria (Hymenoptera: Halictidae): an escape from competitors and enemies? Biol. J. Linn. Soc. 83, 377-387 